\title{
STUDY OF ACOUSTICAL PARAMETERS OF MONOMETHYLAMMONIUM PERCHLORATE IN SOME NON-AQUEOUS SOLVENTS AT DIFFERENT TEMPERATURES USING ULTRASONIC TECHNIQUE
}

\author{
Vivek Pathania $^{1}$, Shrutila Sharma ${ }^{1, *}$, Shashi Kiran Vermani ${ }^{2}$ \\ and B.K.Vermani ${ }^{1}$ \\ ${ }^{1}$ Department of Chemistry, D.A.V.College, Sector-10, Chandigarh-160011, India \\ ${ }^{2}$ Joint Director (Retd.) Higher Education, Haryana, Panchkula-134109, India \\ *E-mail: shrutilasharma@gmail.com
}

\begin{abstract}
Ultrasonic velocity and density for monomethylammonium perchlorate $\left(\mathrm{CH}_{3} \mathrm{NH}_{3} \mathrm{ClO}_{4}\right)$ in non-aqueous solvents Dimethylsulfoxide (DMSO), N, N-Dimethylacetamide (DMA) and Acetonitrile (AN) were measured as a function of molality at temperatures $298 \mathrm{~K}, 308 \mathrm{~K}, 318 \mathrm{~K}$ and $328 \mathrm{~K}$ using DSA 5000M (Anton Paar density and sound velocity meter). Using this data, various acoustical parameters like adiabatic compressibility $\left(\mathrm{K}_{\mathrm{s}}\right)$, apparent molal volume $\left(\mathrm{V}_{\Phi}\right)$, specific acoustic impedance $(\mathrm{Z})$, intermolecular free lengths $\left(\mathrm{L}_{\mathrm{f}}\right)$ and relative association $\left(\mathrm{R}_{\mathrm{A}}\right)$ have been determined. The variation of the acoustical parameters studied with molal concentration is then explored to understand the fundamental picture of various intermolecular interactions taking place.

Keywords: Apparent Molal Volume, Specific Acoustic Impedance, Intermolecular Free Lengths, Acetonitrile, Dimethylacetamide, Dimethylsulfoxide
\end{abstract}

(c) RASĀYAN. All rights reserved

\section{INTRODUCTION}

Density and sound velocity measurements are useful to determine various acoustical parameters like adiabatic compressibility $\left(\mathrm{K}_{\mathrm{s}}\right)$, apparent molal volume $\left(\mathrm{V}_{\boldsymbol{\Phi}}\right)$, relative association $\left(\mathrm{R}_{\mathrm{A}}\right)$, intermolecular free lengths $\left(\mathrm{L}_{\mathrm{f}}\right)$ and specific acoustic impedance $(\mathrm{Z})$, which are very helpful in understanding solvent structure, ion-solvent and ion-ion interactions in pure and binary mixtures of solvents. ${ }^{1}$ These measurements are very important in many chemical processes, industrial applications and theoretical research. $^{2-8}$ A literature survey reveals that no work has been done for the solutions of monomethylammonium perchlorate $\left(\mathrm{CH}_{3} \mathrm{NH}_{3} \mathrm{ClO}_{4}\right)$ in DMSO, DMA and AN solvent system from the perspective of their density and sound velocity measurements. Methylammonium perchlorate $\left(\mathrm{CH}_{3} \mathrm{NH}_{3} \mathrm{ClO}_{4}\right)$ is used as one of the main ingredients in rocket propellants, missiles and explosives. Due to internal aging and other factors involved, thousand of tons of these explosives get wasted every year. Therefore, non-aqueous solvents can be used as a solvating medium to recover the effective components $\left(\mathrm{CH}_{3} \mathrm{NH}_{3} \mathrm{ClO}_{4}\right)$ from these waste composite propellants. ${ }^{9,10}$ Keeping this in view we have studied various acoustical parameters for $\mathrm{CH}_{3} \mathrm{NH}_{3} \mathrm{ClO}_{4}$ in DMSO, DMA and AN over the concentration range $0.03-0.28 \mathrm{~mol} \mathrm{~kg}^{-1}$ at four different temperatures $(298 \mathrm{~K}, 308 \mathrm{~K}, 318 \mathrm{~K}$ and $328 \mathrm{~K})$. The acoustical studies of electrolytes in these solvents in general, is of interest because they have high dipole moment and high dielectric constant $\left(\mu_{\mathrm{DMSO}}=3.90 \mathrm{D}, \mu_{\mathrm{AN}}=3.37 \mathrm{D}, \mu_{\mathrm{DMA}}=3.72 \mathrm{D}, \mathrm{D}_{\mathrm{DMSO}}=46.7\right.$, $\mathrm{D}_{\mathrm{DMA}}=37.8$ and $\mathrm{D}_{\mathrm{AN}}=36.0$ ) and are extensively used as extracting solvents due to their excellent solvating ability. The results are elucidated in terms of various acoustical parameters like adiabatic compressibility $\left(\mathrm{K}_{\mathrm{s}}\right)$, apparent molal volume $\left(\mathrm{V}_{\boldsymbol{\Phi}}\right)$, relative association $\left(\mathrm{R}_{\mathrm{A}}\right)$, intermolecular free lengths $\left(\mathrm{L}_{\mathrm{f}}\right)$ and specific acoustic impedance $(\mathrm{Z})$, which have been obtained from calculated sound velocities and densities of salt solution. The sign and magnitude of these parameters and their variations with salt

Rasayan J. Chem., 13(1), 264-274(2020)

http://dx.doi.org/10.31788/RJC.2020.1315615

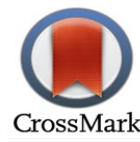


RASĀYAN J. Chem.

Vol. 13 | No. 1 |264 - 274| January - March | 2020

concentration will help us to elucidate the nature of various molecular interactions taking place within the solutions.

Table-1: Source and Purity of Solvents

\begin{tabular}{l|c|c|c|c}
\hline \multicolumn{1}{c|}{ Solvent } & Provenance & CAS-number & Mass Fraction Purity & Content of Water \\
\hline Acetonitrile & E.Merck & $75-05-8$ & $0.999^{\mathrm{a}}$ & $0.00030^{\mathrm{b}}$ \\
\hline $\begin{array}{l}\text { N,N- } \\
\text { Dimethylacetamide }\end{array}$ & E.Merck & $127-19-5$ & $0.999^{\mathrm{a}}$ & $0.00009^{\mathrm{b}}$ \\
\hline Dimethylsulfoxide & E.Merck & $67-68-5$ & $0.999^{\mathrm{a}}$ & $0.00020^{\mathrm{b}}$ \\
\hline Acetone & E.Merck & $67-64-1$ & $0.999^{\mathrm{a}}$ & $0.00021^{\mathrm{b}}$ \\
\hline $\begin{array}{l}{ }^{\mathrm{a}} \text { From Gas Chromatography Analysis } \\
{ }^{\mathrm{b}} \text { Karl-Fischer Titration Method }\end{array}$
\end{tabular}

\section{Source and Purity of Material}

DMSO (99.8\%), DMA (99.8\%), AN (99.8\%) and Acetone (99.8\%), all from E.Merck, were purified by the methods as reported earlier ${ }^{11-14}$. After purification of $\mathrm{AN}$ and DMSO, they have dried over $4 \mathrm{~A}^{\circ}$ molecular sieves while DMA and Acetone were dried over $3 \mathrm{~A}^{\circ}$ molecular sieves before use for $72 \mathrm{~h}$. Silver perchlorate monohydrate $\left(\mathrm{AgClO}_{4} \mathrm{H}_{2} \mathrm{O}\right)$ (Alfa Aesar), was used without further purification for the present investigation. The properties of these solvents after purification have been described briefly in Table 1 . The sound velocity $(\mathrm{u})$ and density $(\rho)$ for DMSO, DMA and AN at temperatures $298 \mathrm{~K}, 308 \mathrm{~K}, 318 \mathrm{~K}$ and $328 \mathrm{~K}$, which were used for interpretation of present data is reported in Table-2.

\section{Salt Preparation}

$\mathrm{CH}_{3} \mathrm{NH}_{3} \mathrm{ClO}_{4}$ was prepared by reacting silver perchlorate monohydrate $\left(\mathrm{AgClO}_{4} \mathrm{H}_{2} \mathrm{O}\right)$ with monomethylammonium chloride (methylamine hydrochloride) $\mathrm{MeNH}_{3} \mathrm{Cl}$ (TCI Chemicals) dissolved in aqueous acetone mixtures in 1:1 molar ratio. White precipitates of silver chloride $(\mathrm{AgCl})$ separated out. The precipitates were filtered and the filtrate was concentrated by evaporation till the volume of the filtrate was reduced to $2 / 3^{\text {rd }}$, the solution was again filtered and heated till the salt separated out. The salt obtained was then recrystallized twice from anhydrous acetone and dried at $60^{\circ} \mathrm{C}$ under vacuum for 3 days. Characterization of the salt was done by elemental analysis $(\mathrm{C}, \mathrm{H}, \mathrm{N}$ and $\mathrm{O})$ and perchlorate content in the salt was calculated by a gravimetric analysis that relies on the insolubility of potassium perchlorate in absolute ethanol (Table-3). ${ }^{15}$

Table-2: Density $\rho\left(\mathrm{Kgm}^{-3}\right)$, Sound Velocity $\mathrm{u}\left(\mathrm{ms}^{-1}\right)$ and Isentropic Compressibility $\left(\mathrm{Ks} / 10^{-10}\right)\left(\mathrm{N}^{-1} \mathrm{~m}^{2}\right)$ for $\mathrm{AN}$, DMA and DMSO at $298 \mathrm{~K}, 308 \mathrm{~K}, 318 \mathrm{~K}$ and $328 \mathrm{~K}$.

\begin{tabular}{|c|c|c|c|c|c|c|c|c|c|c|c|c|}
\hline \multirow{2}{*}{ Solvent } & \multicolumn{3}{|c|}{$298 \mathrm{~K}$} & \multicolumn{3}{|c|}{$308 \mathrm{~K}$} & \multicolumn{3}{|c|}{$318 \mathrm{~K}$} & \multicolumn{3}{|c|}{$328 \mathrm{~K}$} \\
\hline & $\rho$ & $\mathrm{u}$ & $\mathrm{Ks}$ & $\rho$ & $\mathrm{u}$ & $\mathrm{Ks}$ & $\rho$ & $\mathrm{u}$ & $\mathrm{Ks}$ & $\rho$ & $\mathrm{U}$ & $\mathrm{Ks}$ \\
\hline AN & $\begin{array}{c}777.204 \\
776.850^{\mathrm{a}}\end{array}$ & $\begin{array}{c}1278.62 \\
1280.80^{\mathrm{a}}\end{array}$ & $\begin{array}{c}7.860 \\
7.846^{\mathrm{b}}\end{array}$ & $\begin{array}{c}767.188 \\
765.650^{\mathrm{c}}\end{array}$ & 1242.27 & 8.446 & $\begin{array}{c}755.873 \\
754.632^{c}\end{array}$ & 1198.58 & 9.209 & $\begin{array}{c}744.727 \\
743.466^{\mathrm{c}}\end{array}$ & 1158.77 & 10.0 \\
\hline DMA & $\begin{array}{c}937.436 \\
936.232^{c}\end{array}$ & $\begin{array}{l}1459.12 \\
1457.40^{\mathrm{d}}\end{array}$ & 5.009 & $\begin{array}{l}928.211 \\
926.996^{c}\end{array}$ & $\begin{array}{l}1419.32 \\
1417.5^{\mathrm{d}}\end{array}$ & 5.348 & $\begin{array}{l}919.720 \\
917.736^{c}\end{array}$ & $\begin{array}{c}1380.51 \\
1378.20^{d}\end{array}$ & 5.705 & $\begin{array}{l}911.592 \\
908.435^{\mathrm{c}}\end{array}$ & $\begin{array}{c}1349.12 \\
1339.20^{d}\end{array}$ & 6.027 \\
\hline DMSO & $\begin{array}{c}1095.233 \\
1095.283^{\mathrm{x}}\end{array}$ & $\begin{array}{l}1486.74 \\
1484.63^{\mathrm{x}}\end{array}$ & $\begin{array}{l}4.120 \\
4.084^{\mathrm{e}}\end{array}$ & $\begin{array}{c}1085.448 \\
1085.242^{\mathrm{x}}\end{array}$ & $\begin{array}{c}1457.68 \\
1450.62^{\mathrm{x}}\end{array}$ & 4.336 & $\begin{array}{l}1075.241 \\
1075.208^{\mathrm{x}}\end{array}$ & $\begin{array}{l}1421.22 \\
1417.52^{\mathrm{x}}\end{array}$ & 4.604 & $\begin{array}{c}1065.234 \\
1065.092^{d}\end{array}$ & 1388.02 & 4.873 \\
\hline
\end{tabular}

${ }^{a}[\text { Reference } 24]^{b}[\text { Reference } 25]^{c}[\text { Reference } 26]^{d}[\text { Reference } 27]^{x}[\text { Reference } 28]^{e}$ [Reference 29]

Table-3: Elemental Analysis and Perchlorate Content $\left(\mathrm{ClO}_{4}{ }^{-}\right)$Data of the Salt

\begin{tabular}{c|c|c|c|c|c}
\hline $\mathrm{CH}_{3} \mathrm{NH}_{3} \mathrm{ClO}_{4}$ & $\mathrm{C}$ & $\mathrm{H}$ & $\mathrm{N}$ & $\mathrm{O}$ & $\mathrm{ClO}_{4}^{-}$ \\
\hline Found (\%) & $9.372 \%$ & $4.841 \%$ & $11.111 \%$ & $47.606 \%$ & $75.53 \%$ \\
\hline Theoretical(\%) & $9.125 \%$ & $4.599 \%$ & $10.646 \%$ & $48.666 \%$ & $75.66 \%$ \\
\hline
\end{tabular}

\section{Measurements}

Sound velocities and Densities of pure solvents and solutions were evaluated using DSA 5000M (Anton 
RASĀYAN J. Chem.

Vol. 13 | No. 1 |264 - 274| January - March | 2020

Paar digital Density and Sound velocity meter). The instrument has an inbuilt Peltier-type thermostatic unit for maintaining constant temperature and the frequency of the instrument was set at $3 \mathrm{MHz}$ for measuring ultrasonic velocity. Calibration of the instrument was done with triply distilled water and dry air at pressure $0.1 \mathrm{MPa}$. Accuracy for a single measurement of sound velocity and density was found to be $7 \times 10^{-3} \mathrm{~kg} / \mathrm{m}^{3}$ and $0.5 \mathrm{~ms}^{-1}$ respectively. The uncertainty in ultrasonic velocities was found to be better than $\pm 5 \times 10^{-2} \mathrm{~ms}^{-1}$. The reliability of density and sound velocity measurements were confirmed by comparing the obtained data of pure solvents-DMSO, DMA and AN with literature values (Table-2). For obtaining working solutions, stock solutions of suitable concentrations were diluted to the desired extent. Stock solutions were prepared by mass, weighed by ACZET-602CY having a precision of $0.1 \mathrm{mg}$. The plausible molality error was found to be $\pm 1 \times 10^{-4} \mathrm{~mol} \mathrm{~kg}^{-1}$. Prepared solutions were kept in glass bottles (airtight stoppered) for avoiding the absorption of moisture.

\section{Theory and Calculations}

Measured values of ultrasonic velocities ( $\mathrm{u}$ ) and densities $(\rho)$ were used to evaluate different acoustical parameters using the following standard expressions. ${ }^{16,17}$

$$
\begin{array}{ll}
\text { Adiabatic compressibility } & K_{S}=\frac{1}{u^{2} \rho} \\
\text { Apparent molal volume } & V_{\varphi}=\frac{M}{\rho}-\frac{10^{3}\left(p-\rho_{\rho}\right)}{\operatorname{mp} \rho \rho_{\rho}}
\end{array}
$$

Where $\rho_{o}$ is the density of pure solvent and $\rho$ is the density of the solution, $\mathrm{M}$ is the molar mass of solute and $\mathrm{m}$ is molality.

Intermolecular free length $\quad \mathrm{L}_{\mathrm{f}}=\mathrm{k}\left(\mathrm{K}_{\mathrm{s}}\right)^{1 / 2}$

Where $\mathrm{k}$ is Jacobson's constant (temperature dependent), value of which can be calculated by using the relation, $\mathrm{k}=(91.368+0.3565 \mathrm{~T}) \times 10^{-8}$, where $\mathrm{T}$ is the experimental temperature.

Specific acoustic impedance $(Z)=u \times \rho$

Relative association $\left(R_{A}\right)=\left(\rho / \rho_{o}\right) \times\left(u_{0} / u\right)^{1 / 3}$

Where $\mathrm{u}_{\mathrm{o}}$ is the sound velocity of pure solvent and $\mathrm{u}$ is the sound velocity of the solution.

\section{RESULTS AND DISCUSSION}

Ultrasonic velocities (u) and densities $(\rho)$ of $\mathrm{CH}_{3} \mathrm{NH}_{3} \mathrm{ClO}_{4}$ were measured at concentrations range 0.03$0.28 \mathrm{~mol} \mathrm{~kg}^{-1}$ in DMSO, DMA and AN at temperatures $298 \mathrm{~K}, 308 \mathrm{~K}, 318 \mathrm{~K}$ and $328 \mathrm{~K}$. A perusal of Fig. -1 and Fig.-2 shows that sound velocity and density increases linearly with increase in the concentration of electrolyte solution at experimental temperature and decreases as the temperature increases. ${ }^{18,19}$ Possible explanation for fall in the values of sound velocity and density with the rise in temperature would be, therefore, the enfeebling of solute-solvent interactions because of increasing thermal motion of molecules that result in volume expansion due to disordering of DMSO, DMA and AN solvent molecules. Increase in the values of sound velocity and density with enhancing concentration may be explained on the basis of the association, which is occurring between solute-solvent molecules leading to the capturing of solute in solvent molecules cavity due to which solvent-solvent dispersion forces changes and more efficient solute-solvent dispersion forces are introduced resulting in volume compression hence density and ultrasonic velocity increases. ${ }^{20}$ Also, we find that ultrasonic velocity and density values for all three solvents at $298 \mathrm{~K}$ are in the order; DMSO $>$ DMA $>$ AN Fig.-1(a) and 2(a). Similar trends have been obtained at temperatures $308 \mathrm{~K}, 318 \mathrm{~K}$ and $328 \mathrm{~K}$ as can be seen from Tables- 4 to 6 .

The isentropic compressibility $\left(\mathrm{K}_{\mathrm{s}}\right)$ is basically the significant addition of two effects: (a) solvent intrinsic effect as a result of the compression of molecules of solvent, (b) solute intrinsic effect due to the compression of the solvation shell of ions because of the perforation of molecules of solvent into the intrasolute free space, have also been calculated and plotted versus molal concentration at different temperatures. Isentropic compressibility decreases with increasing concentration of electrolyte solution at 
RASĀYAN J. Chem.

Vol. 13 | No. 1 | 264 - 274| January - March | 2020

experimental temperature and increases with the rise in temperature for each of the solvent being studied Fig.-3. Fall in isentropic compressibility with enhancing concentration may be attributed to the dominance of solute intrinsic effect over solvent intrinsic effect. ${ }^{21}$ Also; more cohesion is expected in more concentrated solutions that lead to a decrease in compressibility. An increase in isentropic compressibility with the rise in temperature can be explained on the basis of the increase in kinetic energy of molecules because of increased thermal agitation due to which solvent molecules get released from solute and solution volume increases resulting in decreased compressibility. $K_{s}$ values for each of the solvents at $298 \mathrm{~K}$ follow the order; DMSO $<$ DMA $<$ AN Fig.-3(a). The same order has been obtained at higher temperatures $308 \mathrm{~K}, 318 \mathrm{~K}$ and $328 \mathrm{~K}$ as is clear from Tables- 4 to 6 .
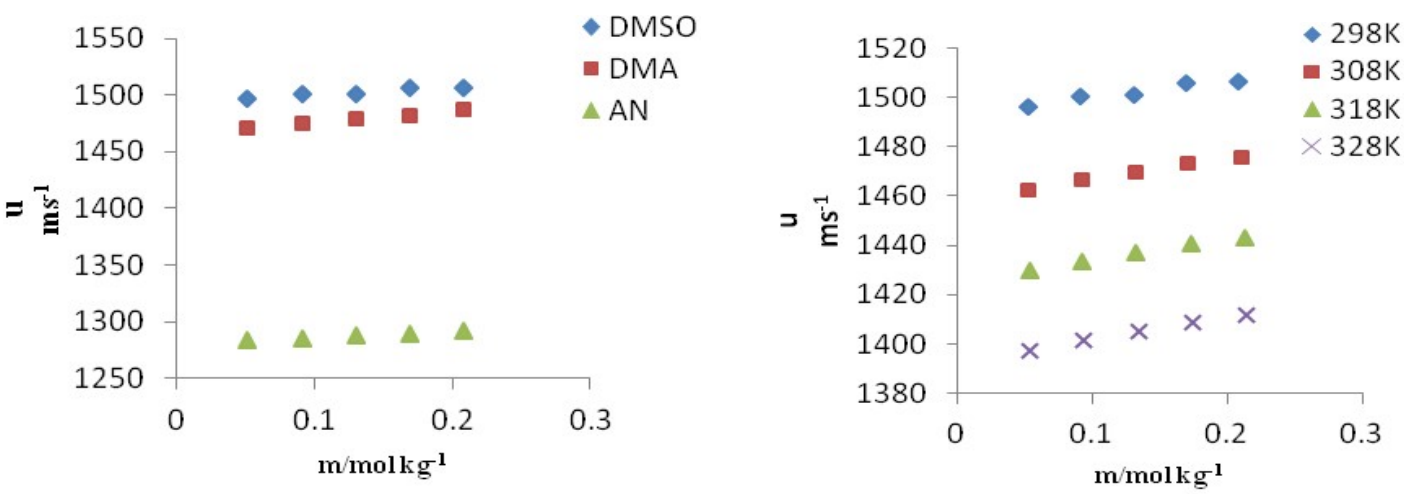

Fig. 1(a) Plots of Ultrasonic velocity (u) versus molal concentration (m) for $\mathrm{CH}_{3} \mathrm{NH}_{3} \mathrm{ClO}_{4}$ in DMSO, DMA and AN at $298 \mathrm{~K}$

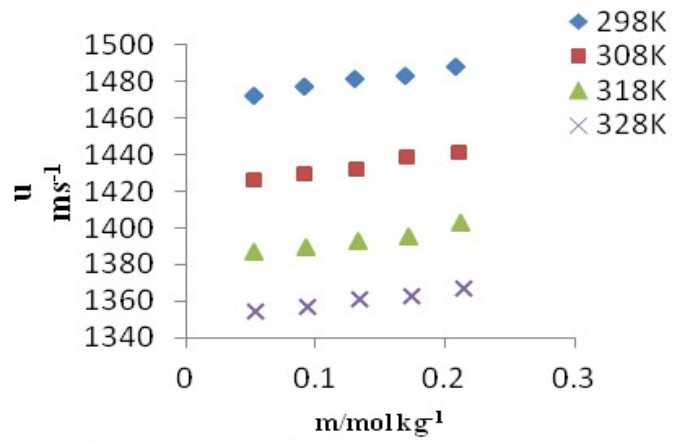

Fig. 1(c) Plots of Ultrasonic velocity (u) versus molal concentration (m) for $\mathrm{CH}_{3} \mathrm{NH}_{3} \mathrm{ClO}_{4}$ in DMA at $298 \mathrm{~K}, 308 \mathrm{~K}, 318 \mathrm{~K}$ and $328 \mathrm{~K}$.

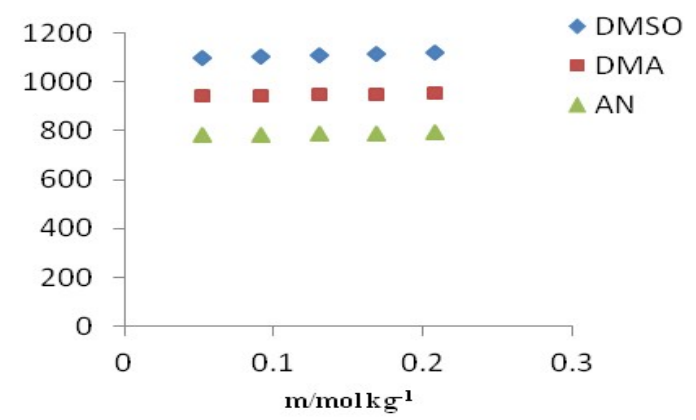

Fig. 2(a) Plots of density ( $p$ ) versus molal concentration (m) for $\mathrm{CH}_{3} \mathrm{NH}_{3} \mathrm{ClO}_{4}$ in DMSO, DMA and $\mathrm{AN}$ at

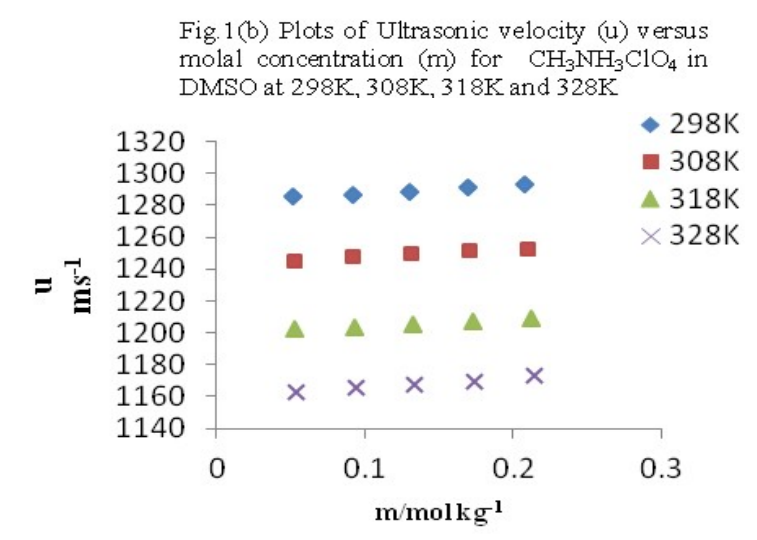

Fig. 1(d) Plots of Ultrasonic velocity (u) versus molal concentration (m) for $\mathrm{CH}_{3} \mathrm{NH}_{3} \mathrm{ClO}_{4}$ in $\mathrm{AN}$ at $298 \mathrm{~K}, 308 \mathrm{~K}, 318 \mathrm{~K}$ and $328 \mathrm{~K}$

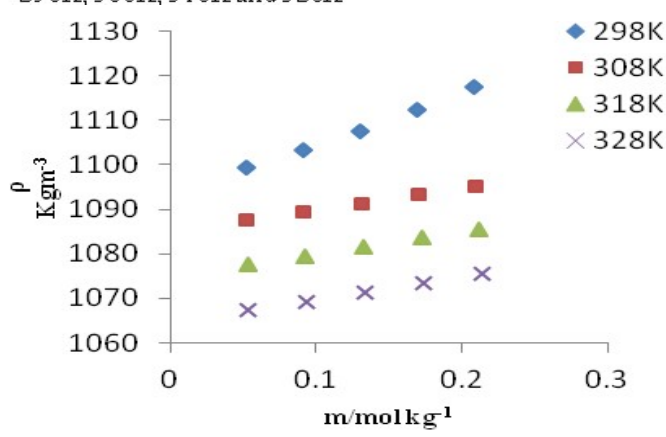

Fig.2(b) Plots of density (p) versus molal concentration $(\mathrm{m})$ for $\mathrm{CH}_{3} \mathrm{NH}_{3} \mathrm{ClO}_{4}$ in DMSO at $298 \mathrm{~K}, 308 \mathrm{~K}, 318 \mathrm{~K}$ and $328 \mathrm{~K}$ 
RASĀYAN J. Chem.

Vol. 13 | No. 1 |264 - 274| January - March | 2020

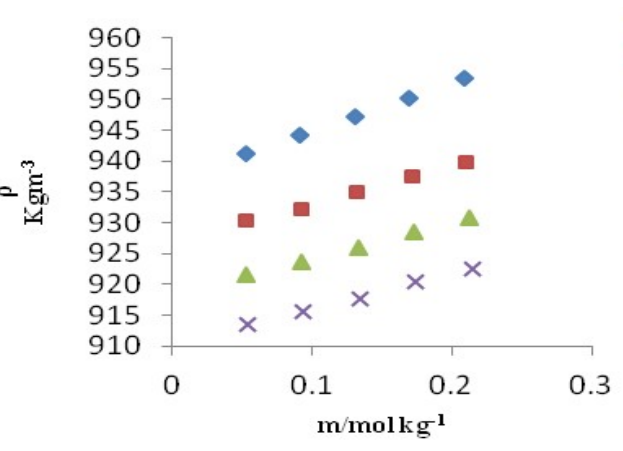

Fig. 2(c) Plots of density ( $p$ ) versus molal concentration (m) for $\mathrm{CH}_{3} \mathrm{NH}_{3} \mathrm{ClO}_{4}$ in DMA at $298 \mathrm{~K}$, $308 \mathrm{~K}, 318 \mathrm{~K}$ and $37.8 \mathrm{~K}$
$-298 K$

$308 \mathrm{~K}$

$\triangle 318 \mathrm{~K}$

$\times 328 \mathrm{~K}$

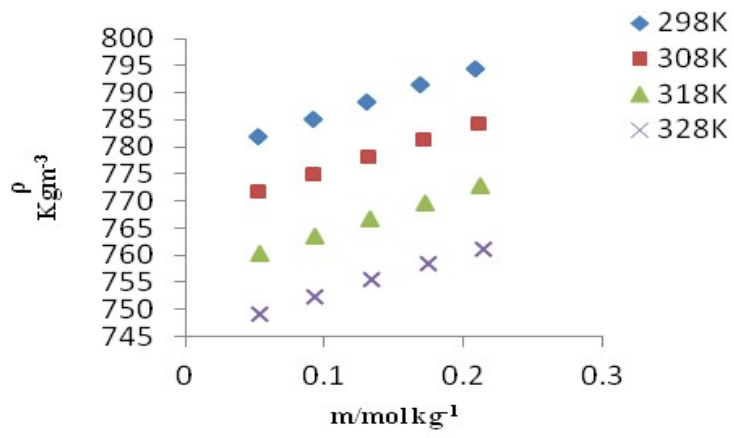

芴

Fig. 2(d) Plots of density ( $p$ ) versus molal concentration (m) for $\mathrm{CH}_{3} \mathrm{NH}_{3} \mathrm{ClO}_{4}$ in $\mathrm{AN}$ at $298 \mathrm{~K}$. $308 \mathrm{~K}, 318 \mathrm{~K}$ and $328 \mathrm{~K}$

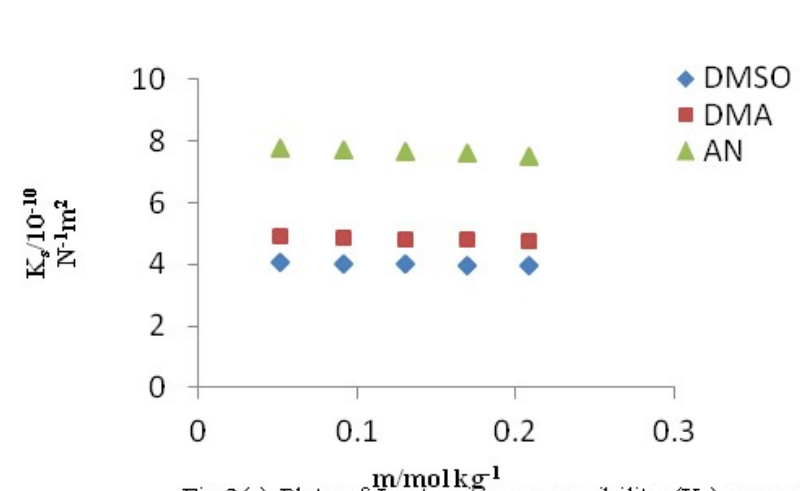

Fig.3(a) Plots of Isentropic compressibility (Ks) v ersus molal concentration (m) for $\mathrm{CH}_{3} \mathrm{NH}_{3} \mathrm{ClO}_{4}$ in DMSO, DMA and AN at $298 \mathrm{~K}$

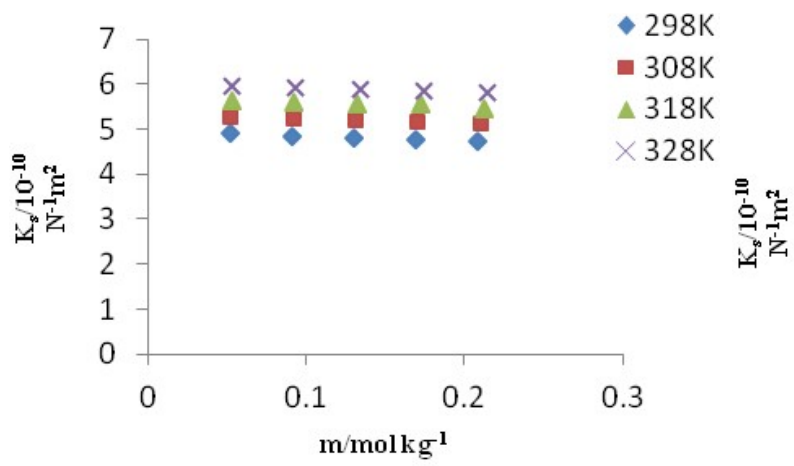

Fig. 3(c) Plots of Isentrop ic compressibility (Ks) versus molal concentration (m) for $\mathrm{CH}_{3} \mathrm{NH}_{3} \mathrm{ClO}_{4}$ in DMA at $298 \mathrm{~K}, 308 \mathrm{~K}, 318 \mathrm{~K}$ and $328 \mathrm{~K}$

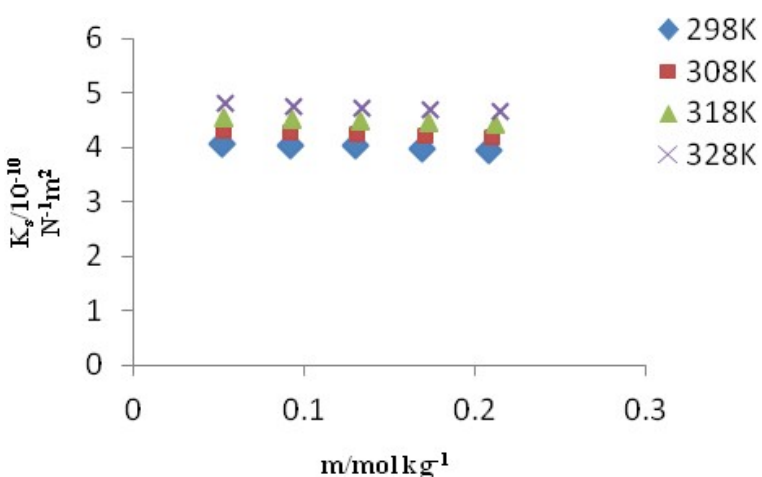

Fig.3(b) Plots of Isentropic compressibility (Ks) versus molal concentration $(\mathrm{m})$ for $\mathrm{CH}_{3} \mathrm{NH}_{3} \mathrm{ClO}_{4}$ in DMSO at $298 \mathrm{~K}, 308 \mathrm{~K}, 318 \mathrm{~K}$ and $328 \mathrm{~K}$

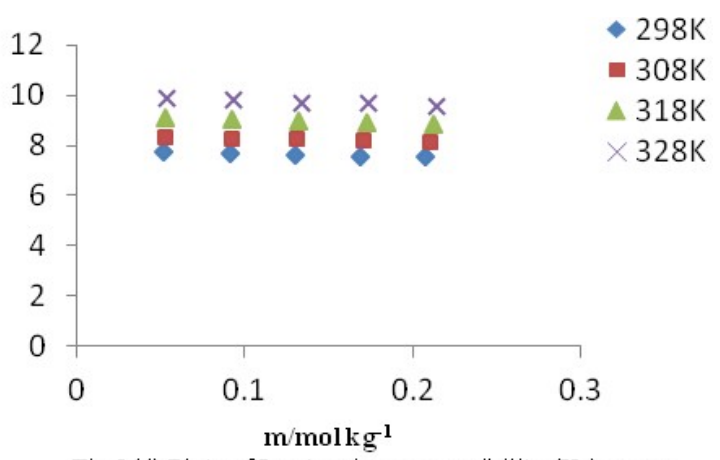

Fig.3(d) Plots of Isentrop ic compressibility (Ks) versus molal concentration (m) for $\mathrm{CH}_{3} \mathrm{NH}_{3} \mathrm{ClO}_{4}$ in $\mathrm{AN}$ at $298 \mathrm{~K}$. $308 \mathrm{~K}, 318 \mathrm{~K}$ and $328 \mathrm{~K}$

Specific acoustic impedance $(\mathrm{Z})$ is the hindrance provided by the liquid medium to the ultrasonic wave and provides information about the medium's elastic property which depends upon different structural transformations taking place in the solution. ${ }^{20}$ Specific acoustic impedance (Z) raises almost linearly with the rise in solution's concentration at all studied temperatures and decreases with elevation in temperature for DMSO, DMA and AN solvents Fig. 4(b)-4(d). Also, for each one of the solvents at 298K, Z values follow the order, DMSO $>$ DMA $>$ AN Fig. 4(a). These values have been found to follow the same order at higher temperatures-308K, $318 \mathrm{~K}$ and $328 \mathrm{~K}$ (Table 4-6). Increasing values of acoustic impedance $(\mathrm{Z})$ with increasing salt concentration at constant temperature can be justified on the basis of strong molecular interactions occurring among molecules of solute and solvent, leaving behind a lesser count of free solvent molecules. Increase in salt concentration results in speeding up the process of breaking solvent 
RASĀYAN J. Chem.

Vol. 13 | No. 1 | 264 - 274| January - March | 2020

molecules clusters and hence becoming the main reason for inhibiting sound waves propagation which may be due to large size of solute molecules that acts like structure promoters, however, increase in temperature increase thermal agitation resulting in release of solvent molecules from solute leaving behind large number of free solvent molecules.

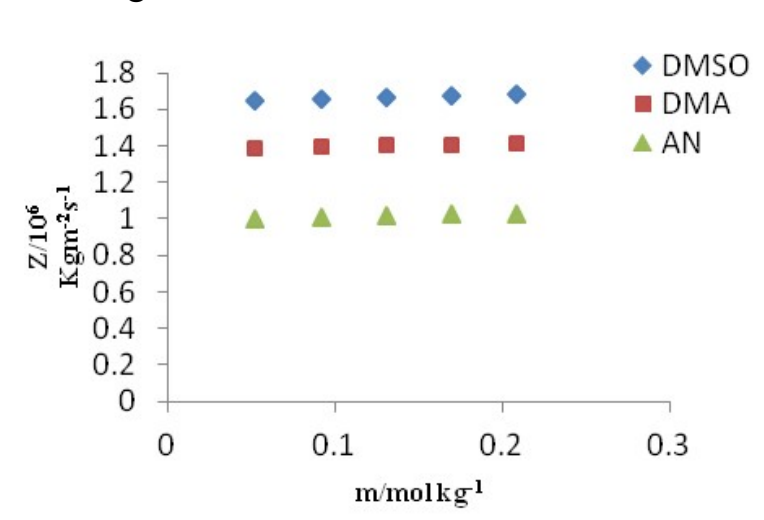

Fig.4(a) Plots of Acoustic impedence ( $Z$ ) versus molal concentration (m) for $\mathrm{CH}_{3} \mathrm{NH}_{3} \mathrm{ClO}_{4}$ in DMSO, DMA and $\mathrm{AN}$ at. $2.98 \mathrm{~K}$

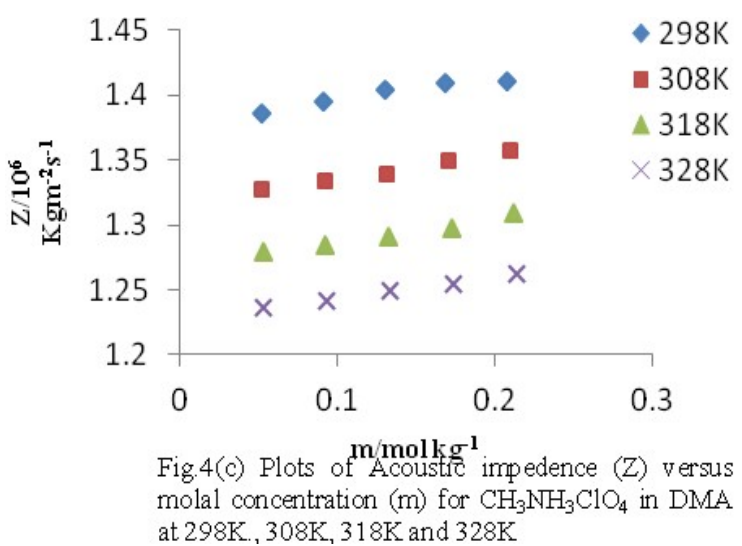

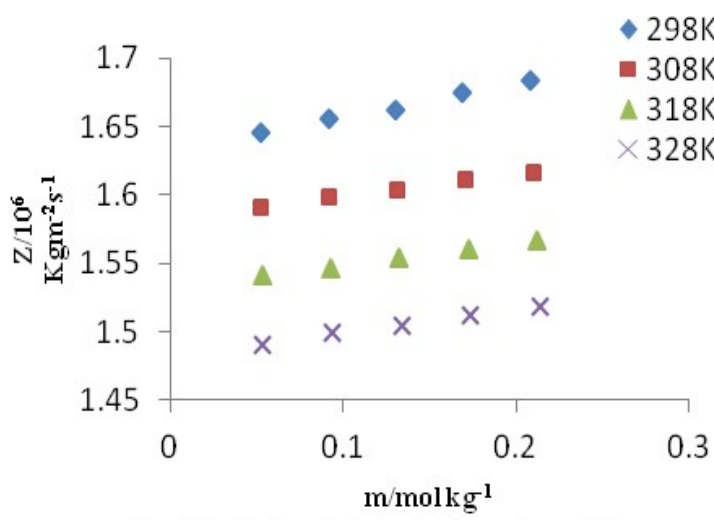

Fig.4(b) Plots of Acoustic impedence ( $Z$ ) versus molal concentration (m) for $\mathrm{CH}_{3} \mathrm{NH}_{3} \mathrm{ClO}_{4}$ in DMSO at $298 \mathrm{~K}, 308 \mathrm{~K}, 318 \mathrm{~K}$ and $328 \mathrm{~K}$

Variation of apparent molal volume $\left(\mathrm{V}_{\Phi}\right)$ with concentration is very important to elucidate the ion-ion and ion-solvent interactions in the electrolyte solutions. The lower value of apparent molal volume examines better packing, hence improved interaction among the molecules of solute-solvent. Figure-5(a) displays the variation of apparent molal volume with a molal concentration of solution for DMSO and DMA mixtures at $298 \mathrm{~K}$. The same trends have been obtained at higher temperatures-308K, $318 \mathrm{~K}$ and $328 \mathrm{~K}$ (Tables- 4 and 5). The decrease in apparent molal volume with an increase in salt concentration in DMSO and DMA solutions at all the studied temperatures indicates the presence of efficient interactions among solute and solvent molecules, however, in $\mathrm{AN}$ solution, $\mathrm{V}_{\Phi}$ values are increasing with the increase in the concentration of solution at experimental temperatures Fig.-5(b).

An increase in $V_{\Phi}$ values with increase in salt concentration is an indication of ionic association occurring in the solution due to to which the interactions among ion and solvent molecules are weakened and hence contraction of the solvent volume would lower slowly as the concentration of the solution is increased. This results in a net positive volume change per mole of the added solute. Another explanation would be decreased in electrostriction as a result molecule of solvent in the solvation sheath will be compressed to a small extent so that when external pressure is applied, these molecules will be more compressible than those present in the bulk of the solution. ${ }^{22}$ This indicates that the change of solvent nature has a remarkable influence on the apparent molal volume. Also, $\mathrm{V}_{\Phi}$ values increase with a rise in the temperature for all the solvent systems considered (Tables-4 to 6). The size of primary and secondary solvation layers around the alkylammonium ions $\left(\mathrm{RNH}_{3}{ }^{+}\right)$can be considered as the main cause of this 
RASĀYAN J. Chem.

Vol. 13 | No. 1 |264 - 274| January - March | 2020

behavior. When the temperature is high, the secondary solvation layer expands due to increased thermal agitation, which enhances the apparent molal volume.

Table-4: Ultrasonic Velocities (u), Densities ( $\rho$ ), Adiabatic Compressibilities $\left(\mathrm{K}_{\mathrm{s}}\right)$, Specific Acoustic Impedance $(\mathrm{Z})$, Apparent Molal Volume $\left(\mathrm{V}_{\varphi}\right)$, Inter Molecular Free Lengths $\left(\mathrm{L}_{\mathrm{f}}\right)$ and Relative Association $\left(\mathrm{R}_{\mathrm{A}}\right)$ for

$\mathrm{CH}_{3} \mathrm{NH}_{3} \mathrm{ClO}_{4}+$ DMSO System at $298 \mathrm{~K}, 308 \mathrm{~K}, 318 \mathrm{~K}$ and $328 \mathrm{~K}$

\begin{tabular}{|c|c|c|c|c|c|c|c|}
\hline $\begin{array}{c}\text { Conc./ } \\
\text { mol kg }^{-1}\end{array}$ & $\begin{array}{c}\mathrm{u} \\
\mathrm{ms}^{-1}\end{array}$ & $\begin{array}{c}\rho \\
\mathrm{Kgm}^{-3} \\
\end{array}$ & $\begin{array}{c}\mathrm{K}_{\mathrm{s}} / 10^{-10} \\
\mathrm{~N}^{-1} \mathrm{~m}^{2}\end{array}$ & $\begin{array}{c}\mathrm{Z} / 10^{6} \\
\mathrm{Kgm}^{-2} \mathrm{~s}^{-1} \\
\end{array}$ & $\begin{array}{c}\mathrm{V}_{\Phi} \\
\mathrm{cm}^{3} \mathrm{~mol}^{-1} \\
\end{array}$ & $\begin{array}{c}\mathrm{L}_{\mathrm{f}} / 10^{-11} \\
\mathrm{~m}\end{array}$ & $\mathrm{R}_{\mathrm{A}}$ \\
\hline \multicolumn{8}{|c|}{$298 \mathrm{~K}$} \\
\hline 0.0520 & 1496.13 & 1099.330 & 4.064 & 1.645 & 53.35 & 3.98 & 1.002 \\
\hline 0.0914 & 1500.55 & 1103.358 & 4.025 & 1.656 & 46.90 & 3.96 & 1.004 \\
\hline 0.1303 & 1501.89 & 1107.420 & 4.003 & 1.662 & 41.50 & 3.95 & 1.008 \\
\hline 0.1690 & 1505.98 & 1112.250 & 3.964 & 1.675 & 36.30 & 3.93 & 1.011 \\
\hline 0.2080 & 1506.23 & 1117.520 & 3.944 & 1.683 & 30.20 & 3.92 & 1.016 \\
\hline \multicolumn{8}{|c|}{$308 \mathrm{~K}$} \\
\hline 0.0525 & 1462.52 & 1087.821 & 4.299 & 1.591 & 83.00 & 4.17 & 1.001 \\
\hline 0.0919 & 1466.80 & 1089.700 & 4.266 & 1.598 & 82.20 & 4.15 & 1.002 \\
\hline 0.1313 & 1469.90 & 1091.792 & 4.241 & 1.604 & 80.60 & 4.14 & 1.003 \\
\hline 0.1707 & 1473.20 & 1094.211 & 4.214 & 1.611 & 77.00 & 4.13 & 1.004 \\
\hline 0.2101 & 1475.63 & 1096.532 & 4.193 & 1.616 & 76.00 & 4.12 & 1.005 \\
\hline \multicolumn{8}{|c|}{$318 \mathrm{~K}$} \\
\hline 0.0530 & 1429.99 & 1077.582 & 4.538 & 1.541 & 84.80 & 4.36 & 1.000 \\
\hline 0.0925 & 1433.70 & 1079.359 & 4.507 & 1.547 & 83.40 & 4.35 & 1.001 \\
\hline 0.1324 & 1437.30 & 1081.425 & 4.476 & 1.554 & 81.60 & 4.33 & 1.002 \\
\hline 0.1723 & 1440.60 & 1083.628 & 4.446 & 1.561 & 79.98 & 4.32 & 1.003 \\
\hline 0.2122 & 1443.25 & 1085.513 & 4.422 & 1.567 & 79.52 & 4.31 & 1.004 \\
\hline \multicolumn{8}{|c|}{$328 \mathrm{~K}$} \\
\hline 0.0535 & 1397.00 & 1067.440 & 4.800 & 1.491 & 86.90 & 4.56 & 0.9725 \\
\hline 0.0936 & 1401.50 & 1069.350 & 4.760 & 1.499 & 84.80 & 4.54 & 0.9732 \\
\hline 0.1338 & 1404.90 & 1071.220 & 4.729 & 1.505 & 83.30 & 4.53 & 0.9741 \\
\hline 0.1740 & 1408.90 & 1073.320 & 4.694 & 1.512 & 81.90 & 4.51 & 0.9751 \\
\hline 0.2142 & 1411.54 & 1075.410 & 4.667 & 1.518 & 80.50 & 4.50 & 0.9764 \\
\hline
\end{tabular}
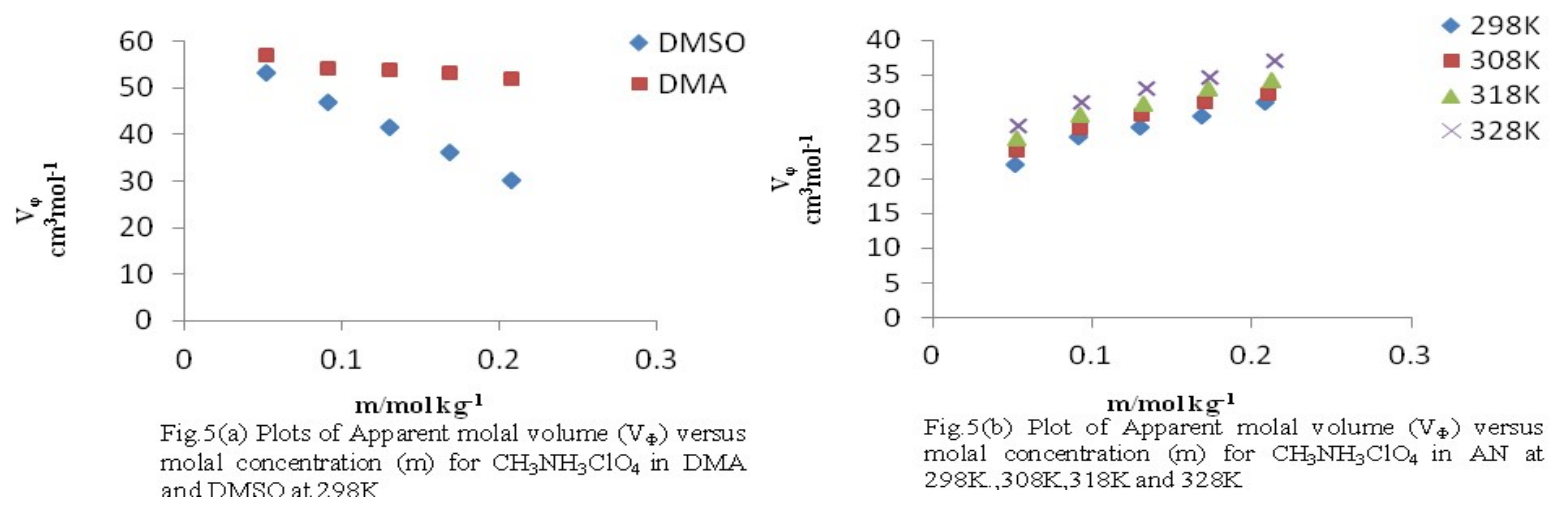

Fig. 5(b) Plot of Apparent molal volume $\left(V_{\Phi}\right)$ versus molal concentration (m) for $\mathrm{CH}_{3} \mathrm{NH}_{3} \mathrm{ClO}_{4}$ in $\mathrm{AN}$ at $298 \mathrm{~K}, 308 \mathrm{~K}, 318 \mathrm{~K}$ and $328 \mathrm{~K}$

The relative association is the parameter that gives the clue about the chemistry behind various molecular interactions taking place within the solution and also measures the non-ideality of solution. The relative association is mainly affected by two opposing factors:

(1) Collapsing structures and associated solvent molecules when a solute is added to it that results in diminishing relative association $\left(\mathrm{R}_{\mathrm{A}}\right)$

(2) Solvating solute by free molecules of solvent that enhances relative association.

STUDY OF MONOMETHYLAMMONIUM PERCHLORATE

270 
RASĀYAN J. Chem.

Vol. 13 | No. 1 |264 - 274| January - March | 2020

Relative association $\left(\mathrm{R}_{\mathrm{A}}\right)$ increases linearly with an increase in the concentration of electrolyte solutions of DMSO (Fig.-6) at all studied temperatures. Exactly the same trends of $\mathrm{R}_{\mathrm{A}}$ versus molal concentration have been obtained in DMA and AN mixture (Tables- 5 and 6).

Table-5: Ultrasonic Velocities (u), Densities ( $\rho$ ), Adiabatic Compressibilities $\left(\mathrm{K}_{\mathrm{s}}\right)$, Specific Acoustic Impedance (Z), Apparent Molal Volume $\left(\mathrm{V}_{\Phi}\right)$, Inter Molecular Free Lengths $\left(\mathrm{L}_{\mathrm{f}}\right)$ and Relative Association $\left(\mathrm{R}_{\mathrm{A}}\right)$ for $\mathrm{CH}_{3} \mathrm{NH}_{3} \mathrm{ClO}_{4}+\mathrm{DMA}$ System at $298 \mathrm{~K}, 308 \mathrm{~K}, 318 \mathrm{~K}$ and $328 \mathrm{~K}$

\begin{tabular}{|c|c|c|c|c|c|c|c|}
\hline $\begin{array}{c}\text { Conc./ } \\
\text { mol kg }\end{array}$ & $\begin{array}{c}\mathrm{u} \\
\mathrm{ms}^{-1}\end{array}$ & $\begin{array}{c}\rho \\
\mathrm{Kgm}^{-3} \\
\end{array}$ & $\begin{array}{c}\mathrm{K}_{\mathrm{s}} / 10^{-10} \\
\mathrm{~N}^{-1} \mathrm{~m}^{2} \\
\end{array}$ & $\begin{array}{c}\mathrm{Z} / 10^{6} \\
\mathrm{Kgm}^{-2} \mathrm{~s}^{-1} \\
\end{array}$ & $\begin{array}{c}\mathrm{V}_{\Phi} \\
\mathrm{cm}^{3} \mathrm{~mol}^{-1} \\
\end{array}$ & $\begin{array}{c}\mathrm{L}_{\mathrm{f}} / 10^{-11} \\
\mathrm{~m}\end{array}$ & $\mathrm{R}_{\mathrm{A}}$ \\
\hline \multicolumn{8}{|c|}{$298 \mathrm{~K}$} \\
\hline 0.0520 & 1472.40 & 941.315 & 4.900 & 1.386 & 55.05 & 4.37 & 1.000 \\
\hline 0.0914 & 1477.10 & 944.314 & 4.853 & 1.395 & 54.18 & 4.35 & 1.002 \\
\hline 0.1303 & 1481.30 & 947.266 & 4.811 & 1.404 & 53.84 & 4.33 & 1.004 \\
\hline 0.1690 & 1483.21 & 950.235 & 4.783 & 1.409 & 53.35 & 4.32 & 1.007 \\
\hline 0.2080 & 1488.15 & 953.387 & 4.736 & 1.410 & 52.09 & 4.30 & 1.010 \\
\hline \multicolumn{8}{|c|}{$308 \mathrm{~K}$} \\
\hline 0.0525 & 1426.12 & 930.309 & 5.285 & 1.327 & 95.12 & 4.62 & 1.000 \\
\hline 0.0919 & 1429.60 & 932.315 & 5.248 & 1.334 & 89.37 & 4.60 & 1.001 \\
\hline 0.1313 & 1432.08 & 935.010 & 5.215 & 1.339 & 80.91 & 4.59 & 1.003 \\
\hline 0.1707 & 1438.85 & 937.449 & 5.152 & 1.349 & 77.99 & 4.56 & 1.005 \\
\hline 0.2101 & 1441.71 & 939.747 & 5.119 & 1.357 & 76.93 & 4.55 & 1.007 \\
\hline \multicolumn{8}{|c|}{$318 \mathrm{~K}$} \\
\hline 0.0530 & 1387.13 & 921.713 & 5.638 & 1.279 & 98.21 & 4.86 & 1.000 \\
\hline 0.0925 & 1389.11 & 923.725 & 5.610 & 1.284 & 91.28 & 4.85 & 1.001 \\
\hline 0.1324 & 1393.01 & 926.091 & 5.564 & 1.291 & 85.42 & 4.83 & 1.002 \\
\hline 0.1723 & 1395.35 & 928.502 & 5.553 & 1.297 & 81.89 & 4.82 & 1.005 \\
\hline 0.2122 & 1403.11 & 930.825 & 5.456 & 1.309 & 80.17 & 4.78 & 1.006 \\
\hline \multicolumn{8}{|c|}{$328 \mathrm{~K}$} \\
\hline 0.0535 & 1354.18 & 913.472 & 5.969 & 1.237 & 101.6 & 5.09 & 1.000 \\
\hline 0.0936 & 1357.11 & 915.501 & 5.930 & 1.242 & 93.54 & 5.07 & 1.001 \\
\hline 0.1338 & 1361.01 & 917.600 & 5.883 & 1.249 & 89.61 & 5.05 & 1.002 \\
\hline 0.1740 & 1363.01 & 920.369 & 5.848 & 1.255 & 82.77 & 5.04 & 1.005 \\
\hline 0.2142 & 1366.84 & 922.523 & 5.802 & 1.262 & 81.80 & 5.02 & 1.006 \\
\hline
\end{tabular}

An increase in $R_{A}$ values with an increase in salt concentration reveals that solvation of solute predominates over the collapsing of the solvent structure that enhances solute's solvation by free solvent molecules. Also, $R_{A}$ values for DMSO solutions have been found to be decreasing with an increase in temperature, however, in DMA and AN solvent systems, $\mathrm{R}_{\mathrm{A}}$ values remain almost constant with an increase in temperature (Tables-5 and 6). The decrease in relative association with a rise in temperature may be accredited to increased thermal motion of molecules resulting in the breakup of associated molecules of solvent from solute which hinders the relative association.

Intermolecular free length $\left(\mathrm{L}_{\mathrm{f}}\right)$ is one of the important thermodynamic properties of liquid which is derived from ultrasonic velocity and density and depends upon intermolecular attractive and repulsive forces. There is a direct relation between intermolecular free length and adiabatic compressibility. ${ }^{23}$ It is a predominant parameter in determining the existing interactions between various components of the solution. Analyzing Fig-7(b) and 7(d) reflects that free length lowers with increasing solution concentration at experimental temperature and increases with the rise in temperature in DMSO, DMA and AN mixtures.

For each of the three solvents studied at $298 \mathrm{~K}, \mathrm{~L}_{\mathrm{f}}$ values follow the order; DMSO $<$ DMA $<$ AN, Fig.-7(a), similar trend as that of isentropic compressibility and same order have been obtained at higher temperatures-308K, $318 \mathrm{~K}$ and $328 \mathrm{~K}$ (Tables- 4 to 6 ). 
RASĀYAN J. Chem.

Vol. 13 | No. 1 |264 - 274| January - March | 2020

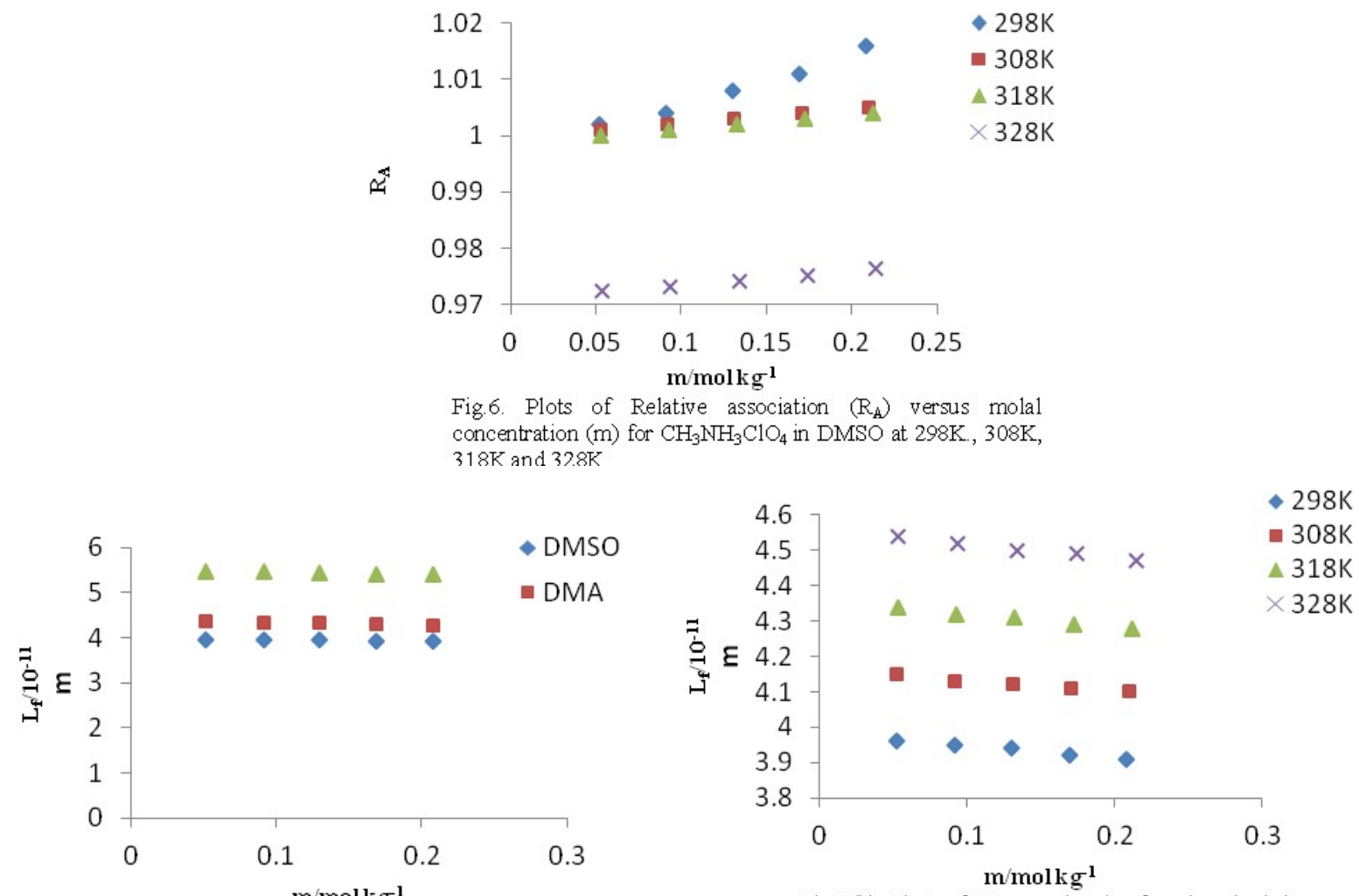

Fig.7(a) Plots of Inter molecular free length $\left(L_{4}\right)$ versus molal concentration (m) for $\mathrm{CH}_{3} \mathrm{NH}_{3} \mathrm{ClO}_{4}$ DMSO, DMA and AN at $298 \mathrm{~K}$.

( molal concentration (m) for $\mathrm{CH}_{3} \mathrm{NH}_{3} \mathrm{ClO}_{4}$ in $\mathrm{DMSO}$ at $298 \mathrm{~K}, 308 \mathrm{~K}, 318 \mathrm{~K}$ and $328 \mathrm{~K}$

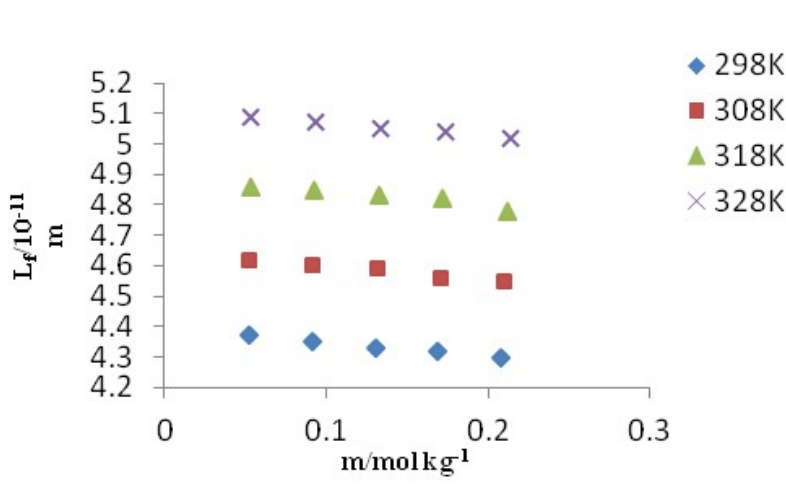

Fig. 7(c) Plots of Inter molecular free length $\left(\mathrm{L}_{\mathrm{f}}\right)$ versus molal concentration (m) for $\mathrm{CH}_{3} \mathrm{NH}_{3} \mathrm{ClO}_{4}$ in DMA at $298 \mathrm{~K}, 308 \mathrm{~K}, 318 \mathrm{~K}$ and $328 \mathrm{~K}$

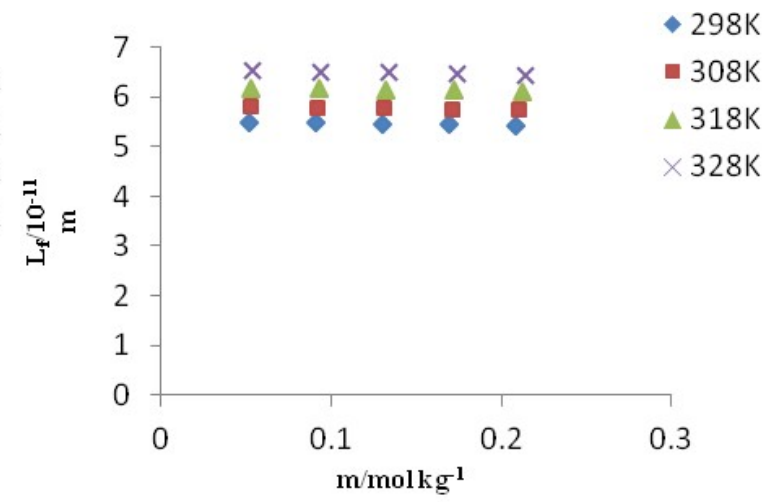

Fig.7(d) Plots of Inter molecular free length $\left(\mathrm{L}_{\mathrm{f}}\right)$ versus molal concentration (m) for $\mathrm{CH}_{3} \mathrm{NH}_{3} \mathrm{ClO}_{4}$ in $\mathrm{AN}$ at $298 \mathrm{~K}, 308 \mathrm{~K}, 318 \mathrm{~K}$ and $328 \mathrm{~K}$

Table-6: Ultrasonic Velocities (u), Densities ( $\rho)$, Adiabatic Compressibilities $\left(\mathrm{K}_{\mathrm{s}}\right)$, Specific Acoustic Impedance $(\mathrm{Z})$, Apparent Molal Volume $\left(\mathrm{V}_{\varphi}\right)$, Intermolecular Free Lengths $\left(\mathrm{L}_{\mathrm{f}}\right)$ and Relative Association $\left(\mathrm{R}_{\mathrm{A}}\right)$ for $\mathrm{CH}_{3} \mathrm{NH}_{3} \mathrm{ClO}_{4}+\mathrm{AN}$ System at 298K, 308K, 318K and 328K

\begin{tabular}{|c|c|c|c|c|c|c|c|}
\hline $\begin{array}{c}\text { Conc./ } \\
\text { mol kg }{ }^{-1}\end{array}$ & $\begin{array}{c}\mathrm{u} \\
\mathrm{ms}^{-1}\end{array}$ & $\begin{array}{c}\rho \\
\mathrm{Kgm}^{-3} \\
\end{array}$ & $\begin{array}{c}\mathrm{K}_{\mathrm{s}} / 10^{-10} \\
\mathrm{~N}^{-1} \mathrm{~m}^{2}\end{array}$ & $\begin{array}{c}\mathrm{Z} / 10^{6} \\
\mathrm{Kgm}^{-2} \mathrm{~s}^{-1} \\
\end{array}$ & $\begin{array}{c}\mathrm{V}_{\Phi} \\
\mathrm{cm}^{3} \mathrm{~mol}^{-1} \\
\end{array}$ & $\begin{array}{c}\mathrm{L}_{\mathrm{f}} / 10^{-11} \\
\mathrm{~m}\end{array}$ & $\mathrm{R}_{\mathrm{A}}$ \\
\hline \multicolumn{8}{|c|}{$298 \mathrm{~K}$} \\
\hline 0.0520 & 1285.18 & 781.801 & 7.744 & 1.005 & 22.67 & 5.49 & 1.004 \\
\hline 0.0914 & 1286.69 & 784.999 & 7.694 & 1.010 & 27.70 & 5.48 & 1.008 \\
\hline 0.1303 & 1288.67 & 788.213 & 7.639 & 1.016 & 28.84 & 5.46 & 1.011 \\
\hline 0.1690 & 1291.13 & 791.417 & 7.579 & 1.022 & 29.29 & 5.44 & 1.015 \\
\hline 0.2080 & 1293.51 & 794.394 & 7.524 & 1.028 & 31.62 & 5.42 & 1.018 \\
\hline
\end{tabular}


RASĀYAN J. Chem.

Vol. 13 | No. 1 |264 - 274| January - March | 2020

\begin{tabular}{|c|c|c|c|c|c|c|c|}
\hline \multicolumn{8}{|c|}{$308 \mathrm{~K}$} \\
\hline 0.0525 & 1245.39 & 771.715 & 8.354 & 0.9611 & 23.96 & 5.81 & 1.004 \\
\hline 0.0919 & 1247.78 & 774.895 & 8.289 & 0.9668 & 28.47 & 5.79 & 1.008 \\
\hline 0.1313 & 1249.77 & 778.129 & 8.227 & 0.9725 & 29.16 & 5.77 & 1.011 \\
\hline 0.1707 & 1251.22 & 781.291 & 8.168 & 0.9775 & 30.44 & 5.75 & 1.015 \\
\hline 0.2101 & 1252.89 & 784.292 & 8.122 & 0.9826 & 32.28 & 5.73 & 1.018 \\
\hline \multicolumn{8}{|c|}{$318 \mathrm{~K}$} \\
\hline 0.0530 & 1202.32 & 760.359 & 9.102 & 0.9098 & 25.33 & 6.18 & 1.004 \\
\hline 0.0925 & 1203.16 & 763.470 & 9.048 & 0.9186 & 29.66 & 6.16 & 1.008 \\
\hline 0.1324 & 1205.07 & 766.660 & 8.982 & 0.9239 & 30.86 & 6.14 & 1.012 \\
\hline 0.1723 & 1206.80 & 769.680 & 8.921 & 0.9288 & 33.00 & 6.12 & 1.015 \\
\hline 0.2122 & 1208.96 & 772.773 & 8.853 & 0.9343 & 33.79 & 6.09 & 1.019 \\
\hline \multicolumn{8}{|c|}{$328 \mathrm{~K}$} \\
\hline 0.0535 & 1163.07 & 749.135 & 9.868 & 0.8713 & 27.58 & 6.54 & 1.003 \\
\hline 0.0936 & 1165.92 & 752.279 & 9.779 & 0.8771 & 30.68 & 6.51 & 1.007 \\
\hline 0.1338 & 1167.35 & 755.448 & 9.713 & 0.8819 & 31.57 & 6.49 & 1.011 \\
\hline 0.1740 & 1168.97 & 758.348 & 9.649 & 0.8865 & 34.59 & 6.47 & 1.014 \\
\hline 0.2142 & 1173.57 & 761.205 & 9.538 & 0.8933 & 36.98 & 6.43 & 1.018 \\
\hline
\end{tabular}

The decrease in free length with a salt concentration in the solution may be due to an increase in the strength of hydrogen bonding and dipole-dipole interactions while the increase in free length with molality may be due to weakening of dipolar association and hydrogen bonding due to increased thermal agitation with an increase in temperature.

\section{CONCLUSION}

It is concluded from results that interactions among solute and solvent reinforces with rising in solution concentration that implies structural denseness as well as tight solvation layer formation around methylammonium perchlorate $\left(\mathrm{CH}_{3} \mathrm{NH}_{3} \mathrm{ClO}_{4}\right)$ which is substantiated by lowering of apparent molal compressibility $\left(\mathrm{K}_{\mathrm{s}}\right)$ and intermolecular free length $\left(\mathrm{L}_{\mathrm{f}}\right)$ with rising in the molal concentration of the solution. Overall, somewhat lower values of $\mathrm{K}_{\mathrm{s}}$ and $\mathrm{L}_{\mathrm{f}}$ for DMSO than those for DMA and AN solutions suggest stronger interactions among ion-solvent molecules in DMSO mixtures. Decrease in apparent molal volume $\left(\mathrm{V}_{\phi}\right)$ with increasing salt concentration in case of DMSO and DMA solvent systems indicated ionic dissociation, however, more negative slopes obtained for DMSO than for DMA shows more efficient solute-solvent interactions in DMSO mixtures and positive slopes in AN mixtures explained the existence of strong solute-solute interactions due to stronger ionic association in this solvent system. Increasing values of relative association $\left(R_{A}\right)$ and specific acoustic impedance $(Z)$ with an increasing salt concentration in the solution for each of the three solvents studied forms the basis of strong interactions among solute-solvent molecules leaving behind a lesser number of free molecules of solvent. All the parameters including $\mathrm{K}_{\mathrm{s}}, \mathrm{V}_{\Phi}, \mathrm{Z}, \mathrm{L}_{\mathrm{f}}$ and $\mathrm{R}_{\mathrm{A}}$ in common revealed that in all the studied systems increase in temperature results in a decrease of solvation due to thermal agitation which leads to the release of solvent molecules from solute thereby inhibit the solvation phenomenon. Conclusively, it can be said that the explication of the acquired results is persistent with the presence of strong molecular association (hydrogen bonding or dipole-dipole interaction or dipole-induced dipole interaction) in DMSO liquid mixtures at $298 \mathrm{~K}$.

\section{ACKNOWLEDGMENT}

The authors wish to thank D.A.V.College, Sector-10, Chandigarh (India) for financial assistance.

\section{REFERENCES}

1. A.N. Sonar and N.S. Pawar, Rasayan Journal of Chemistry, 3(1), 38(2010)

2. D.S. Gill, A. Kumari , R. Gupta, S.P. Jauhar and J.K. Puri, International Journal of Research in Physical Chemistry and Chemical Physics, 219, 1099(2005), DOI: 10.1524/zpch.2005.219.8.1099

3. D. S. Gill,V. Pathania, B. K. Vermani and R. P. Sharma, International Journal of Research in Physical Chemistry and Chemical Physics, 217,739(2003), DOI: 10.1524/zpch.217.6.739.20446 
RASĀYAN J. Chem.

Vol. 13 | No. 1 |264 - 274| January - March | 2020

4. D. S. Gill, H. Anand, A. Kumari and J. K. Puri, A Journal of Physical Sciences, 59a, 615(2004), DOI: $10.1515 /$ zna-2004-0912

5. D. S. Gill, V. Pathania, A. Kumari, H. Anand and S. P. Jauhar, International Journal of Research in Physical Chemistry and Chemical Physics , 218, 857(2004), DOI:10.1524/zpch.218.7.857.35729

6. A. D. Aprano, F. Accascino and R. M. Fuoss, Journal of Solution Chemistry, 19, 65(1990), DOI: 10.1007/BF00650645

7. L. Maravkova and J. Linek, The Journal of Chemical Thermodynamics, 35, 1139(2003), DOI: $10.1016 / \mathrm{S} 0021-9614(03) 00077-6$

8. C. Yang, Z. Liu, H. Lei and P. Ma, Journal of Chemical Engineering Data, 51, 457(2006), DOI: $10.1021 / \mathrm{je} 050376 \mathrm{y}$

9. W. S. Melvin and J. F. Graham, Method to Demilitarize, extract and recover Ammonium perchlorate from Composite propellants using liquid ammonia. U.S. Patent 34,419, Oct 26, (1993)

10. J. C. Watts and P. A. Larson, 2002, In Kirk-Othmer Encyclopedia of Chemical Technology, Ed.2.

11. M. N. Roy, A. Banerjee and R. K. Das, The Journal of Chemical Thermodynamics, 41, 1187(2009), DOI: $10.1016 /$ j.jct.2009.03.005

12. A. Riddick, W. B. Bunger and T. K. Sakano, 1986, Organic solvents, Physical Properties and Methods of Purification. Wiley Interscience, New York, 4th Ed.

13. A. Wypych- Stasiewicz, A. Borun, J. Benko and A. Bald, Journal of Molecular Liquids, 178, 84(2013), DOI:10.1016/j.molliq.2012.11.028

14. A. Wypych-Stasiewicz, A. Borun, J. Benko and A. Bald, Journal of Molecular Liquids, 190, 54(2014), DOI:10.1016/j.molliq.2013.10.023

15. G. Hefter, Monatshefte fur Chemie-Chemical Monthly,149, 323(2018)

16. R. Palani, A. Geetha and R. K. Swara, Rasayan Journal of Chemistry, 2(3), 602(2009)

17. R. Palani, A. Geetha, S. Saravanan and Vijaya Shanbhag, Rasayan Journal of Chemistry, 1(3), 495(2008)

18. A. Ali, A. K. Nain and M. Kamil, Thermochimica Acta, 274,209(1996), DOI:10.1016/00406031(95)02719-X

19. A. Ali and A. K. Nain, Acoustic Letters, 19,181(1996)

20. S. Singh, M. Talukdar and U. N. Dash, Journal of Molecular Liquids, 249, 815(2018), DOI:10.1016/j.molliq.2017.11.099

21. D. Das, B. Das and D. K. Hazra, Journal of Molecular Liquids, 111,15(2004), DOI:10.1016/j.molliq.2003.09.017

22. R. K. Wadi, Vinita and R. Kakkar, Indian Journal of Chemistry, 39A,598(2000)

23. A. Ali, S. Hyder and A. K. Nain, Indian Journal Physics, 74B(1), 63(2000)

24. D. S. Gill, R. Singh, H. Anand and J. K. Puri, Journal of Molecular Liquids, 98,15(2002), DOI: 10.1016/S0167-7322(01)00303-8

25. H. Anand and R. Verma, International Journal of Research in Physical Chemistry and Chemical Physics, 230(2), 185(2016), DOI:10.1515/zpch-2015-0636

26. J. Krakowiak, D. Bobicz and W. Grzybkowski, Journal of Molecular Liquids, 88,197(2000), DOI: 10.1016/S0167-7322(00)00154-9

27. H. Zarei and V. Keley, Journal of Chemical Engineering Data, 62, 913(2017), DOI:10.1021/acs.jced.6b00496

28. L. Marcinkowski, A. Kloskowski, J. Czub, J. Namiesnik and D. Warminska, Journal of Chemical Thermodynamics, 88, 36(2015), DOI:10.1016/j.jct.2015.04.006

29. H. Anand and R. Verma, Chemical Science Transaction,7(3), 488(2018), DOI:10.7598/cst2018.1506

[RJC-5615/2019] 